\title{
MUSEUM LAMPUNG SEBAGAI MEDIA PEMBELAJARAN SEJARAH
}

\author{
Umi Hartati \\ Program Studi Pendidikan Sejarah, FKIP Universitas Muhammadiyah Metro \\ email: umihartati46@yahoo.com
}

\begin{abstract}
Abstrak
Penelitian ini bertujuan untuk mengetahui pelaksanaan pembelajaran sejarah dengan memanfaatkan Museum Lampung sebagai alternatif media pembelajaran sejarah di dalam kelas. Jenis penelitian ini adalah kualitatif deskriptif. Teknik pengumpulan data yang digunakan adalah wawancara, observasi dan dokumen. Setelah data terkumpul, data akan divalidasi dengan cara trianggulasi. Teknik analisis data yang digunakan adalah model interaktif. Hasil penelitian ini menunjukkan bahwa sebelum pelaksanaan pembelajaran dimulai guru terlebih dahulu menentukan SK \& KD, merancang metode, membuat RPP, menyiapkan media dan membuat pertanyaan. Pelaksanaan pembelajaran terdiri dari tiga tahapan yaitu, kegiatan awal, kegiatan inti (eksplorasi, elaborasi, konfirmasi), dan kegiatan akhir.

Kata kunci : Museum Lampung, Pembelajaran Sejarah, SMA Negeri 1 Seputih Agung.
\end{abstract}

\begin{abstract}
This study aims to investigate the implementation of the teaching pf history by utilizing the Museum Lampung as an alternative medium of learning history in the classroom. This type of research is qualitative descriptive. Data collection techniques used were interviews, observation, and documents, after the data will be validated by means of triangulation. Data analysis technique used is the alternative model. The results of this study indicate that prior to the implementation of the learning begins, teachers must first determine SK \& KD, desidning methods, create lesson plans, preparing media, and make inquiries, learning implementation consists of three stages, namely initial activity, the core activities (exploration, elaboration, confirmation) and the final activity.
\end{abstract}

Keywords: Museum Lampung, Teaching History, SMA Negeri 1 Seputih Agung.

\section{PENDAHULUAN}

Pendidikan sejarah merupakan media pendidikan yang paling ampuh untuk memperkenalkan kepada peserta didik tentang bangsanya di masa lampau. Melalui pelajaran sejarah peserta didik dapat melakukan kajian mengenai apa dan bila, mengapa, bagaimana, serta akibat apa yang timbul dari jawaban masyarakat bangsa di masa lampau tersebut terhadap tantangan yang mereka hadapi serta dampaknya bagi kehidupan pada masa sesudah peristiwa itu dan masa kini (Hamid Hasan, 2010:6).

Dalam hal ini museum mempunyai kaitan yang sangat erat dengan dunia pendidikan. Museum mempunyai peranan penting dalam dunia pendidikan dengan menjalankan fungsinya sebagai lembaga pendidikan non formal. Museum menjadi sarana belajar tanpa mengambil peran dari seorang guru. Museum merupakan lembaga non profit yang bersifat tetap untuk melayani masyarakat dan terbuka untuk umum. Museum juga dapat 
meningkatkan kesadaran para pelajar terhadap peristiwa masa lalu. Selain itu juga, museum dapat memberikan kontribusi untuk pendidikan sekolah dalam banyak hal, yang paling penting komunikasi visual melalui benda-benda dan bahan mata pelajaran seperti Sejarah, Geografi, Seni, Fisika, Kimia, Astronomi, Kesehatan dan Kebersihan, Ilmu Pengetahuan Alam dan Matematika bahkan bisa menjadi hidup lebih jelas dan efektif melalui pameran di museum yang ada di museum (Singh Prabhas Kumar, tanpa tahun:74).

Salah satu museum yang dapat dijadikan sebagai bahan referensi yaitu Museum Lampung. Dimana Museum Lampung memiliki peran sebagai sumber pengetahuan masyarakat terutama pelajar yang ingin lebih mengetahui tentang sejarah Lampung. Dalam konteks pembelajaran terhadap pendidikan formal yang dilakukan di sekolah, Museum Lampung harus menempatkan dirinya sebagai sumber pengetahuan dan pengalaman yang dapat mendukung terwujudnya kompetensi peserta didik. Secara umum, Museum Lampung memiliki koleksi benda-benda peninggalan yang sangat bermanfaat untuk dijadikan sebagai media pembelajaran bagi peserta didik maupun guru yang ada di Provinsi Lampung mulai dari tingkat SD sampai dengan SMA maupun Perguruan Tinggi.
Selain itu juga, museum dapat digunakan sebagai media pembelajaran dengan menyesuaikan materi pelajaran. Penggunaan museum sebagai media pembelajaran disebabkan karena kompleksitas media yang tersedia sebagai penjelasan suatu peristiwa. Hal ini memberikan kemudahan bagi peserta didik dalam memahami benda yang dipamerkan. Kemudahan yang diperoleh peserta didik adalah, karena di dalam museum telah disediakan berbagai media yang memberikan informasi. Media tersebut berupa model, realita, tabel, poster atau sistem multimedia elektronik seperti audio visual (Tsabit Azinar Ahmad, 2010:113).

Dalam

pelaksanaan pembelajaran di SMA N 1 Seputih Agung, guru sejarah menggunakan benda-benda koleksi Museum Lampung sebagai contoh yang konkrit dalam pembelajaran sejarah di dalam kelas dengan cara mengemas benda-benda Museum Lampung tersebut dalam media pembelajaran elektronik audio visual yang akan ditayangkan dalam bentuk slide demi slide yang dirangkai menjadi sebuah film interaktif yang akan menampilkan contoh dari benda-benda koleksi Museum Lampung.

Pembelajaran sejarah dengan menjadikan Museum Lampung sebagai salah satu media pembelajaran tentunya akan mampu memberikan kesan tersendiri bagi para peserta didik. Hal 
ini dikarenakan peserta didik tersebut tidak hanya terpaku pada buku, tetapi mereka juga akan mampu melihat secara langsung hasil kebudayaan masyarakat Lampung pada masa lampau tanpa harus berkunjung ke Museum Lampung.

Berdasarkan permasalahan di atas, maka tujuan dari penelitian ini akan dikaji tentang pelaksanaan pembelajaran sejarah dengan memanfaatkan Museum Lampung sebagai alternatif media pembelajaran sejarah di dalam kelas.

\section{METODE PENELITIAN}

Penelitian ini dilaksanakan di SMA Negeri 1 Seputih Agung Lampung Tengah, dengan menggunakan metode penelitian kualitatif dengan analisis deskriptif untuk memperoleh gambaran yang lebih jelas tentang keadaan yang sedang berlangsung dan lebih menekankan pada proses dan makna. Adapun strategi yang digunakan adalah studi kasus tunggal.

Teknik pengumpulan data menggunakan wawancara yang bertujuan untuk memperoleh informasi dalam penelitian kualitatif, jenis wawancara yang akan digunakan adalah wawancara tidak berstruktur dengan nara sumber kepala sekolah, guru sejarah, peserta didik dan pengelola Museum Lampung untuk mendukung argumen atau informasi yang dibutuhkan. Selanjutnya melakukan observasi yang bertujuan untuk mengamati secara langsung interaksi dalam pembelajaran antara guru dan siswa yang menggunakan museum sebagai media pembelajaran sejarah di dalam kelas, dan yang terakhir melalui dokumen untuk sumber data berupa kurikulum untuk mencari standar kopetensi dan kompetensi dasar, silabus untuk melihat materi, indikator, tugas peserta didik, dan sumber belajar. RPP untuk melihat materi tujuan pembelajaran SMA Negeri 1 Seputih Agung, serta foto proses pembelajaran di dalam kelas dan foto benda-benda koleksi museum yang dapat dimanfaatkan sebagi sumber penelitian. Setelah data diperoleh, data akan dideskripsikan dan dianalisis, kemudian akan divalidasi menggunakan teknik trianggulasi. Trianggulasi yang digunakan adalah trianggulasi sumber digunakan untuk memperoleh kebenaran, trianggulasi metode dilakukan dengan cara mengumpulkan data sejenis tetapi dengan menggunakan teknik atau metode pengumpulan data yang berbeda, trianggulasi peneliti adalah hasil peneliti baik data maupun kesimpulan mengenai bagian tertentu atau keseluruhannya bisa diuji validitasnya dari beberapa peneliti yang lain, dan trianggulasi teori dengan menggunakan perspektif lebih dari satu 
dalam membahas permasalahan yang dikaji (H.B. Sutopo, 2006:92-99).

Dalam penelitian kualitatif, teknik analisis data dilakukan dalam bentuk interaktif dengan tiga tahapan yaitu reduksi data, penyajian data, dan penarikan simpulan atau verifikasi (Miles M.B \& Huberman A.M, 1992:20).

\section{HASIL DAN PEMBAHASAN}

Dalam pelaksanaan pembelajaran di dalam kelas dengan memanfaatkan Museum Lampung sebagai media alternatif pembelajaran di SMA Negeri 1 Seputih Agung kelas X, terlebih dahulu guru sejarah harus membuat perencanaan ataupun rancangan pembelajaran.

Perencanaan pembelajaran sangat penting dilakukan oleh seorang guru karena perencanaan tersebut akan menentukan apa yang akan dilakukan oleh seorang guru untuk mengajar peserta didiknya. Perencanaan pembelajaran tersebut dapat disusun berdasarkan kebutuhan dalam jangka waktu yang telah ditentukan oleh seorang guru dan perencanaan tersebut harus dapat dilaksanakan dengan mudah serta tepat pada sasaran yang tentunya tetap berpedoman pada kurikulum.

Guru sejarah kelas X di SMA Negeri 1 Seputih Agung dalam membuat perencanaan pembelajaran hal pertama yang dilakukannya adalah menentukan SK \& KD dengan materi yang berhubungan dengan pemanfaatan media Museum Lampung, selanjutnya merancang metode yang tepat dan sesuai dengan materi yang akan dibahas, membuat RPP, menyiapkan media yang berupa film interaktif, dan yang terakhir membuat pertanyaan untuk melihat sejauh mana kemampuan peserta didik menerima penjelasan materi yang telah disampaikan di dalam kelas selama proses pembelajaran berlangsung.

Perencanaan pembelajaran membutuhkan kerja keras dalam pelaksanaannya sebagai salah satu bentuk profesionalitas guru. Melalui perencanaan pembelajaran, guru mempunyai kesempatan untuk mencurahkan segenap kemampuan, kecerdasan, dan kecakapannya. Hakikatnya ini adalah kesempatan untuk menjadi guru yang benar-benar bermutu (S. K. Kochhar, 2008:561).

Sukses atau tidaknya suatu pembelajaran di dalam kelas akan ditentukan seberapa besar kemantapan ataupun keberhasilan seorang guru dalam membuat perencanaan sebelum melakukan pembelajaran di dalam kelas. Perencanaan pembelajaran memainkan peran penting dalam memandu guru untuk melaksanakan tugas sebagai pendidik dalam melayani kebutuhan belajar peserta didiknya. Perencanaan pembelajaran juga dimaksudkan sebagai langkah awal sebelum proses pembelajaran 
berlangsung. Terdapat beberapa manfaat perencanaan pembelajaran dalam proses pembelajaran yaitu:

a. Sebagai petunjuk arah kegiatan dalam mencapai tujuan.

b. Sebagai pola dasar dalam mengatur tugas dan wewenang bagi setiap unsur yang terlibat dalam kegiatan.

c. Sebagai pedoman kerja bagi setiap unsur, baik unsur guru maupun unsur peserta didik.

d. Sebagai alat ukur efektif tidaknya suatu pekerjaan, sehingga setiap saat diketahui ketepatan dan kelambatan kerja.

e. Untuk bahan penyusunan data agar terjadi keseimbangan kerja.

f. Untuk menghemat waktu, tenaga, alat-alat dan biaya. (Abdul Majid, 2011:22).

Perencanaan pembelajaran sejarah dengan pemanfaatan media Museum Lampung telah sesuai dengan standar kompetensi "Memahami prinsip dasar ilmu sejarah" dan kompetensi dasar "Mendeskripsikan tradisi sejarah dalam masyarakat Indonesia masa praaksara dan masa aksara". Selain itu juga, dalam perencanaan pembelajaran dirancang dengan menggunakan metode pembelajaran yang tepat. Sebenarnya, metode pembelajaran yang tepat yaitu karya wisata, tetapi karya wisata tersebut akan dilaksanakan oleh peserta didik di kelas XI semester genap, maka di kelas $X$ ini hanya akan diberikan contoh dari koleksi yang ada di Museum Lampung dalam bentuk media interaktif.

\section{Setelah}

perencanaan pembelajaran selesai dibuat, maka langkah selanjutnya yaitu mengimplementasikan rencana pembelajaran tersebut dalam kegiatan pembelajaran.

Pelaksanaan pembelajaran merupakan tugas utama bagi seorang guru, dimana pembelajaran dapat diartikan sebagai kegiatan untuk memberikan pengetahuan ataupun pengajaran kepada peserta didiknya. Di dalam pelaksanaan pembelajaran, guru semakin dituntut untuk mampu menciptakan suasana kelas yang kondusif. Suasana kelas harus demokratis, tidak tegang, tetapi harus tetap tertib agar semua peserta didik bisa optimal dalam menyimak, berbicara, dan mengekspresikan dirinya (Luk Luk Alfi Hidayah, 2010:220).

Seperti halnya yang telah diungkapkan oleh Aman (2011:81-82), pelaksanaan proses pembelajaran, merupakan kejadian atau peristiwa interaksi antara pendidik dan peserta didik yang diharapkan menghasilkan perubahan pada peserta didik, dari belum mampu menjadi mampu, dari yang belum terdidik menjadi terdidik, dari yang belum kompeten menjadi kompeten.

$$
\text { pelaksanaan pembelajaran }
$$

sejarah di SMA Negeri 1 Seputih Agung 
dengan pemanfaatan media Museum Lampung sudah baik dan mulai ada kemajuan karena telah menggunakan media pembelajaran berupa koleksikoleksi Museum Lampung yang dapat memberikan informasi tentang sejarah. Selain itu juga dengan memanfaatkan Museum Lampung sebagai media pembelajaran peserta didik cukup antusias mengikuti pelajaran sampai selesai, dikarenakan peserta didik dapat melihat secara langsung koleksi bendabenda yang ada di Museum Lampung yang sesuai dengan materi yang sedang dibahas di kelas dengan menggunakan media interaktif.

Hal ini sesuai dengan KD yang sedang diajarkan yaitu "Mendeskripsikan Tradisi Sejarah Dalam Masyarakat Indonesia Masa Praaksara Dan Masa Aksara". KD tersebut sangat cocok apabila media Museum Lampung dijadikan sebagai pembelajaran sejarah, karena dalam koleksi Museum Lampung menampilkan tradisi sejarah masyarakat Indonesia sebelum mengenal tulisan dan jejak-jejak sejarah Indonesia, sesuai dengan materi yang sedang dibahas di dalam kelas.

Pemanfaatan Museum Lampung sebagai alternatif media dalam pelaksanaan pembelajaran sejarah di SMA Negeri 1 Seputih Agung oleh guru dikemas sedemikian rupa dalam bentuk media interaktif dengan tujuan dapat mempermudah guru dalam menjelaskan materi pelajaran di dalam kelas, karena dengan waktu yang sangat terbatas tidak mungkin peserta didik guru ajak langsung ke Museum Lampung, dengan alasan jarak, waktu dan juga biaya. Selain itu juga, dengan memberikan contoh koleksi-koleksi yang ada di Museum Lampung yang dikemas dalam bentuk media interaktif membuat peserta didik lebih mengetahui dan menghargai budaya ataupun bendabenda bersejarah yang telah diwariskan oleh nenek moyang kita yang berasal dari Lampung itu sendiri, karena selama ini peserta didik kurang dalam pengetahuan dan wawasan serta penghargaan tentang benda-benda bersejarah, dan juga dapat dijadikan sebagai contoh sejarah lokal yang ada di daerah Lampung.

Pada tahap pelaksanaan pembelajaran di kelas yang dilakukan oleh guru terdiri dari tiga kegiatan yaitu (1) Kegiatan Awal. Kegiatan awal ini merupakan kegiatan yang bertujuan untuk menciptakan suasana pembelajaran yang efektif dan mempersiapkan siswa dalam mengikuti kegiatan pembelajaran selanjutnya. Kegiatan awal ini meliputi salam, presensi, apersepsi, dan selanjutnya menyampaikan SK, KD, indikator serta tujuan pembelajaran. (2) Kegiatan Inti. Kegiatan inti dalam pembelajaran ini menggunakan media yang berupa film interaktif untuk membantu guru 
menjelaskan materi kepada peserta didik dengan menampilkan contohcontoh benda koleksi yang ada di Museum Lampung. Dari kegiatan inti ini, guru menanamkan kepada peserta didiknya rasa menghargai budaya ataupun benda-benda bersejarah yang berasal dari Lampung, dan juga menambah wawasan serta penghargaan terhadap benda-benda bersejarah. Dalam pembelajaran sejarah, meliputi tahap eksplorasi, elaborasi dan konfirmasi dan dalam pembelajaran ini menggunakan metode ceramah dan tanya jawab. Sebaiknya dalam pembelajaran sejarah metode ceramah tidak lagi digunakan oleh guru pada saat pembelajaran berlangsung, karena dalam pelaksanaan pembelajaran dengan memanfaatkan media museum dalam bentuk film interaktif ini memberikan ruang yang lebih banyak kepada peserta didik untuk dapat mengungkapkan pendapatnya atau berpikir kritis dalam proses pembelajaran dengan menggunakan media interaktif tersebut, seharusnya guru hanya berperan sebagai fasilitator saja. (3) Kegiatan Akhir. Kegiatan akhir merupakan kegiatan penutup dalam proses pembelajaran di kelas yang lebih berorientasi dilakukan oleh guru untuk melakukan penilaian terhadap kegiatan pembelajaran. Kegiatan tersebut meliputi tahap refleksi, melakukan penilaian terhadap hasil belajar siswa, dan menginformasikan tentang topik atau bahasan pada pertemuan selanjutnya.

Dalam pelaksanaan pembelajaran dengan pemanfaatan Museum Lampung sebagai alternatif media pembelajaran sejarah guru menggunakan media yang berupa film interaktif yang dikemas sedemikian rupa sehingga membuat peserta didiknya lebih aktif dan inovatif dalam mengikuti pelajaran di dalam kelas. Gambar dari benda-benda koleksi Museum Lampung guru kemas dalam slide demi slide yang dikombinasikan dengan sedikit materi sebagai penjelasannya. Dalam kegiatan belajar peserta didik terlihat sangat antusias mengikuti pelajaran sampai selesai dan banyak pertanyaan yang mereka tanyakan mengenai materi yang sedang dibahas.

Dengan penggunaan film sebagai alternatif media belajar, pendidik dan peserta didik dapat menjalin komunikasi dan interaksinya lebih hidup dan bersifat dialogis. Sebab sebagai media, film adalah alat yang dapat membantu proses pembelajaran yang berfungsi memperjelas makna pesan yang disampaikan sehingga tujuan pembelajaran dapat tercapai dengan lebih baik, dan lebih sempurna (Teguh Trianto, 2013:xi).

Dalam pelaksanaan pembelajaran tidaklah berdiri sendiri, tetapi terkait dengan komponen materi dan waktu. 
Seorang guru memiliki peranan penting dalam pelaksanaan pembelajaran. Diantara peranan guru tersebut adalah sebagai berikut:

a. Membuat desain pembelajaran secara tertulis, lengkap dan menyeluruh.

b. Meningkatkan diri untuk menjadi seorang guru yang berkepribadian utuh.

c. Bertindak sebagai guru yang mendidik.

d. Meningkatkan profesionalitas keguruan.

e. Melakukan pembelajaran sesuai dengan berbagai model pembelajaran yang disesuaikan dengan kondisi peserta didik, bahan ajar, dan kondisi sekolah setempat. Penyesuaian tersebut dilakukan untuk peningkatan mutu belajar.

f. Dalam berhadapan dengan siswa, guru berperan sebagai fasilitas belajar, pembimbing belajar, dan pemberi balikan belajar. Dengan adanya peran-peran tersebut, maka sebagai pembelajar guru adalah pembelajar sepanjang hayat (Dimyati \& Mudjiono, 2009:37 dalam Winkel, 19991; Monks, Knoers, Siti Rahayu, 1989; Biggs \& Telfer, 1987).

Sesuai dengan pernyataan di atas telah diterapkan oleh guru sejarah kelas $X$ di SMA Negeri 1 Seputih Agung dengan melakukan berbagai perencanaan pembelajaran sebelum melaksanakan pembelajaran di dalam kelas.

Penggunaan Museum Lampung sebagai alternatif media pembelajaran sejarah dapat bermanfaat untuk membangun kesadaran siswa tentang pentingnya waktu dan tempat yang merupakan sebuah proses dari masa lampau, masa kini, dan masa yang akan datang, melatih daya kritis siswa untuk memahami fakta sejarah secara benar dengan didasarkan pada pendekatan ilmiah dan metodologi keilmuan, menumbuhkan apresiasi dan penghargaan peserta didik terhadap peninggalan sejarah sebagai bukti peradaban Indonesia di masa lampau.

\section{PENUTUP}

\section{Simpulan}

Berdasarkan hasil penelitian terungkap bahwa sebelum melaksanakan proses pembelajaran sejarah dengan menggunakan media Museum Lampung di dalam kelas guru terlebih dahulu harus menyiapkan atau membuat perencanaan pembelajaran. Perencanaan pembelajaran sangat penting dilakukan oleh seorang guru karena perencanaan tersebut akan menentukan apa yang akan dilakukan oleh seorang guru untuk mengajar peserta didiknya.

Setelah perencanaan pembelajaran selesai dibuat, maka langkah selanjutnya yaitu 
mengimplementasikan

rencana

pembelajaran tersebut dalam kegiatan pembelajaran dengan menggunakan koleksi-koleksi yang ada di Museum Lampung yang di kemas dalam bentuk film interaktif sebagai media pembelajaran sejarah di dalam kelas.

\section{Saran}

Berdasarkan hasil penelitian yang telah dikemukakan di atas, maka dapat diberikan saran antara lain:

- Adanya media pembelajaran sejarah dalam bentuk media interaktif ini dapat membantu peserta didik dalam memahami palajaran sejarah di dalam kelas. Peserta didik juga lebih paham akan fungsi dari Museum Lampung itu sendiri ternyata tidak hanya sekedar sarana rekreasi saja, tetapi juga dapat dimanfaatkan sebagai media pembelajaran sejarah.

- Dalam pelaksanaan pembelajaran sejarah dengan memanfaatkan media Museum Lampung harus dapat memanfaatkan media secara optimal agar pembelajaran sejarah dapat bermutu dan berkualitas.

- Dengan adanya penelitian ini, diharapkan muncul penelitian lebih lanjut lagi yang dapat memanfaatkan atau mengembangkan penelitian yang telah diselesaikan, salah satunya mengenai pemanfaatan Museum sebagai media dan sumber belajar.

\section{DAFTAR PUSTAKA}

Aman. 2011. Model Evaluasi Pembelajaran Sejarah. Yogyakarta: Ombak.

Abdul Majid. 2011. Perencanaan Pembelajaran. Bandung: PT Remaja Rosdakarya.

Dimyati \& Mudjiono. 2009. Belajar Dan Pembelajaran. Jakarta: Rineka Cipta.

Hamid Hasan. 2010. Pendidikan Sejarah: Kemana dan Bagaimana. Jurnal Pendidikan Sejarah.

H.B. Sutopo. 2006. Metode Penelitian Kualitatif. Surakarta: UNS.

Luk Luk Alfi Hidayah. 2010. Upaya Guru Dalam Mengatasi Hambatan Pembelajaran Sejarah Pada KTSP Di SMP Negeri 39 Semarang. Jurnal Paramita. Volume 20 No.2.

Miles M.B \& Huberman A.M. 1992. Analisis Data Kualitatif. Jakarta: UI Press.

S. K. Kochhar. 2008. Teaching Of History. Pembelajaran Sejarah. Jakarta: Grasindo.

Singh Prabhas Kumar. Tanpa Tahun. Museum And Education. Journal OHRJ. Volume XIVII. No. 1.

Tsabit Azinar Ahmad. 2010. Strategi Pemanfaatan Museum Sebagai Media Pembelajaran Pada Materi Zaman Prasejarah. Jurnal Paramita. Volume 20 No. 1.

Teguh Trianton. 2013. Film Sebagai Media Belajar. Yogyakarta: Graha Ilmu. 
Museum Lampung Sebagai Media Pembelajaran..., Umi Hartati, 1-10 